\title{
SOCIALE ECONOMIE EN BEDRIJFSECONOMIE
}

\author{
doot H. Reinoud
}

Een toevallige omstandigheid - een overgenomen spreekbeurt van een collega. die op het laatste moment verhinderd was - voerde mij enige jaren geleden naar een bijeenkomst van de Schmalenbach Gesellschaft, waarvan het bestaan mij tot die tijd onbekend was. Sindsdien ontvang ik jaarlijks een uitnodiging tot het bijwonen van een zgn. "Arbeltstagung" van deze vereniging, wier doelstelling .,Förderung der betriebswirtschaftlichen Forschung und Praxis" is.

Kortgeleden werd deze bijeenkomst te Keulen gehouden. Het onderwerp, dat speciaal gekozen bleek met het $\infty$ g op het 25-jarig bestaan der vereniging, was "Bessere Marktanpassung durch unternehmerisches Planen" met als ondertitel .,Wie begegnet die Unternehmensleitung der wachsenden Ausweitung der fixen Kosten und ihrer Auswirkung auf das Unternehmerrisiko?"

Gelijk sommige lezers zich nog wel zullen herinneren trok een in 1928 te Wenen gehouden lezing van Schmalenbach, ..Die Betriebswirtschaftslehre an der Schwelle der neuen Wirtschaftsverfassung", internationaal nogal de aandacht. Schmalenbach's thema was in het kort: door verschillende oorzaken, vooral door de stijging van de kapitaalintensiviteit en de toeneming van de bedrijfsgrootte, nemen de constante kosten (fixe Kosten) relatief snel toe. Om het bekende daaraan verbonden gevaar van chronische verstoring van het evenwicht tussen vraag en aanbod te ontgaan zal deze ontwikkeling in toenemende mate tot ondernemerscombinaties leiden. Daarmede wordt echter tevens het einde van de vrije economie, d.w.z. van een economie gebaseerd op een min of meer volledige mededinging, ingeluid. 1)

Erkennende het nut, dat kartels in deze situatie kunnen hebben, stelt hij evenwel vast, dat zowel hun intern beleid - geen sanering der bedrijven als hun externe bedrijfspolitiek, in het bijzonder hun prijspolitiek - hoge binnenlandse en lage exportprijzen - zeer veel te wensen overlaat. „Die Gedankenlosigkeit auf diesem Gebiete geht so weit, dass nicht einmal eine genaue Kalkulation darüber angestellt wird, wie hoch sich die proportionalen Kosten belaufen. ${ }^{2}$ ) Ein noch grösserer wirtschaftlicher Nonsens besteht darin, dass man nicht alles daran setzt, die übergrosse Kapazität für die Zukunft zu vermeiden. Man macht auf diese Weise die vorübergehende Krankheit zu einer Dauerkrankheit."

En dan profeteert hij: , Ich bin überzeugt, dass wir in nicht zu ferner Zeit zu einem Zustande kommen müssen, den auch die Zünfte besassen; die Monopolgebilde der neuen Wirtschaft müssen ihr Monopol vom Staate empfangen und auf der anderen Seite überwacht der Staat die Erhaltung der aus dem Monopol entspringenden Pflichten."

Schmalenbach zelf merkte later op, dat zijn gedachtengang "Die Zerstörung der freien Wirtschaft durch die fixen Kosten" niet nieuw was, waarbij hij verwees naar beschouwingen van $K$. Wittgenstein voor de Verein für Sozialpolitik in 1894 en naar eigen uitlatingen vóór 1928. ${ }^{3}$ )

In ons land had Prof. Dr Th. Limperg Jr in 1922 op enige soortgelijke verschijnselen als door Schmalenbach genoemd - in het bijzonder de situatie van chronisch prijsbederf door overtollig produktievermogen - gewezen, maar hij zag deze vooral in verband met onvoldoende kennis van de kostprijs bij de ondernemers en zijn beschouwing liep uit op een pleidooi voor een juiste kostprijsberekening en een daarop te baseren prijsstelling. ${ }^{4}$ )

m a b blz. 53 
Schmalenbach's uiteenzetting heeft zowel instemming als felle kritiek ontmoet en nog jaren daarna internationaal de pennen in beweging gebracht.

Hier te lande heeft zijn rede van 1928, voorzover ik kon nagaan, de economische en bedrijfseconomische tijdschriften niet beroerd, maar wel komt in de crisistijden der dertiger jaren de problematiek der constante kosten explicite of implicite in allerlei beschouwingen tot uiting. Prof. $\mathrm{Dr} P$. Lieftinck bijv. bracht het vraagstuk van de constante kosten in verband met chronisch prijsbederf op de internationale markten en met protectiestrevingen $\overline{5}$ ), terwijl de betreffende materie aldus zijn weerslag vond in de memorie van toelichting op het in 1934 ingediende ontwerp van wet tot algemeen verbindend en onverbindend verklaren van ondernemersovereenkomsten: „Elders zijn rationalisatie en concentratie zover doorgevoerd, dat zelfs bij gelijk gebleven afzet een belangrijke overcapaciteit bestaat, die onder de druk der hoge vaste kosten in plaats van tot inperking der productie tot een verdere overvoering der markt leidt, waardoor de rentabiliteit wordt vernietigd."

De plaats der constante kosten in het economisch mechanisme, in het bijzonder ook zoals Schmalenbach die zag, gaf voorts Dr P. J. Verdoorn aanleiding tot een in 1943 gepubliceerde studie .,De verstarring der productiekosten", in andere vorm uitgegeven onder de titel ,De ontwikkeling en druk der constante kosten", waarin hij o.a. tot de conclusie kwam, dat het dubieus is ,of het thema van de toenemenden druk der constante kosten wel zijn oorsprong vindt in den relatieven groei t.o.v. de totale kosten, zooals dit door Schmalenbach gesteld wordt. Eerder ligt de gedachte voor de hand aan een absoluten groei per onderneming, een concentratie der constante kosten, die zich tegelijk met den groei en concentratie der individueele ondernemingen voltrekt". ${ }^{6}$ )

Uit het onderwerp van zijn rede blijkt de betekenis, die Schmalenbach aan het waarnemen en verklaren van de verschijnselen in de bedrijfshuishouding toekende voor de sociale economie. Dit wil overigens niet zeggen, dat Schmalenbach zich altijd een overtuigd voorstander van een samengaan van Volkswirtschaftslehre en Betriebswirtschafslehre heeft betoond; in feite stond hij sterk ambivalent tegenover de relatie sociale economie-bedrijfseconomie. Enerzijds was er bij hem een weten, dat de bedrijfseconomie onlosmakelijk verbonden is met een groter geheel en omgekeerd, anderzijds een nadrukkelijk afstand nemen tot de sociaal-economen. In zijn inleiding tot zijn ".Grundlagen der Selbstkostenrechnung und Preispolitik" schreef hij: „Obwohl ich die Aufgabe betriebswirtschaftlicher Forschung unter gemeinwirtschaftlichen und nicht privatwirtschaftlichen Gesichtspunkten sehe, ist doch dieser Aufsatz weit davon entfernt, ein volkswirtschaftlicher zu sein. Volkswirtschaftslehre und Betriebswirtschaftslehre haben nur einen grossen Teil des Stoffes, nicht aber den Geist gemein. Die Volkswirtschaftslehre ist eine philosophische Wissenschaft mit den ihr anhaftenden Eigentümlichkeiten. Die Betriebswirtschaftslehre in der von mir vertreten Art dagegen ist angewandte Wissenschaft. Chemische und mechanische Technologie sind in ihrem Geiste der Betriebswirtschaftslehre näher verwandt als die Volkswirtschaftslehre." 7)

Prof. Limperg heeft indertijd in dit blad uitvoerig uiteengezet hoe schadelijk het standpunt van Schmalenbach c.s. en de ,antithese tussen de kunstleer der Privatwirtschaftslehre en de economie" in het algemeen voor de ontwikkeling van de bedrijfseconomie als wetenschap zijn geweest. ${ }^{8}$ )

Met dit alles voor ogen was het ongetwijfeld een goede gedachte van 
het Bestuur van de Schmalenbach Gesellschaft om zijn 25-jarig bestaan te herdenken door zowel een sociaal-als een bedrijfseconoom, beiden van de universiteit van Keulen, uit te nodigen Schmalenbach's thema over de invloed van de vaste kosten vanuit de hedendaagse kennis en ervaring te belichten.

De eerste, Prof. Dr Th. Wessels, sprak over .W Wachsende Starrheit der Unternehmungen und ihre Ursachen"; de tweede, Prof. Dr Th. Beste, over , Grössere Elastizität durch unternehmerisches Planen vom Standpunkt der Wissenschaft".

De Schmalenbach Gesellschaft heeft niet de gewoonte de refaraten te voren in enigerlei vorm te verstrekken; van Prof. Wessels waren er echter ditmaal enige stellingen, hoewel zeer beknopt. $\left.{ }^{9}\right)$ Hetgeen ik dan ook hieronder over de uiteenzettingen van Prof. Wessels in eigen bewoordingen mededeel, berust overwegend op goed begrip en verstaan mijnerzijds van het voorgedragene.

De gedachtengang van Schmalenbach, aldus Prof. Wessels, moet gezien worden tegen de achtergrond van het economisch tijdsgebeuren, waarin hij was opgegroeid. Kenmerkend voor dat tijdsgebeuren was, dat tijden van opgang gevolgd werden door vaak langdurige perioden van teruggaande economische bedrijvigheid, waarin de vraag belangrijk achterbleef bij de produktiemogelijkheden, de prijzen veelal scherp daalden en het produktieapparaat over de gehele linie een sterke onderbezetting vertoonde. De analyse van de economische golfbeweging was in die tijd nog onvolkomen, waardoor weinig inzicht bestond in de mogelijkheden om een betekenende en langdurige teruggang van de vraag te voorkomen.

Werd daarom aan een beinvloeding van de vraagfunctie in het algemeen niet serieus gedacht, anders was dit gesteld met de aanbodzijde. Het was bebegrijpelijk dat producenten door onderlinge afspraken de aanbodfactoren en daarmede de gevolgen van de druk van de constante kosten - trachtten te beinvloeden. Evenzeer begrijpelijk was het echter, dat er economen e.a. waren, die deze ondernemersovereenkomsten en de daaruit voortvloeiende invloed op de prijsvorming met zorg gadesloegen, omdat $z$ ij er een verstarring der produktiekosten en prijsstruktuur van vreesden.

De moderne economen, aldus Prof. Wessels, tonen voor de problematiek van de constante kosten, zoals Schmalenbach die zag, niet zoveel belangstelling meer. $Z_{i j}$ denken niet meer in de eerste plaats aan prijzen en kosten, maar aan beinvloeding van het nationaal inkomen, aan de inkomensstromen en de bestedingen.10) Velen van hen zijn van mening dat, al zal het conjunctuurverschijnsel als zodanig altijd blijven bestaan, toch een langdurige en diepgaande teruggang van het economisch leven door een doeltreffende economische politiek is te voorkomen. In deze gedachtengang zullen lange perioden van .,generale Unterbeschäftigung" niet meer voorkomen, waardoor tevens het vraagstuk van de constante kosten in zijn relatie tot de algemene economie, zoals Schmalenbach die zag, belangrijk aan betekenis heeft ingeboet.

Is er in verband met deze gedachtengang geen bijzondere aandacht meer voor de ontwikkeling van de constante kosten, op beperkter schaal, aldus Prof. Wessels, is er nog wel een verwant probleem. Ook wanneer - in de evenbedoelde macro-economische beschouwingswijze - de vraag in totaliteit op een hoog niveau kan worden gehandhaafd, kunnen er toch voor sommige bedrijven met veel ,,vast kapitaal" problemen ontstaan doordat de smaak en de gewoonten van het publiek zich veel sneller wijzigen dan

$\mathrm{m} \mathrm{a} \mathrm{b}$ blz. 55 
vroeger en daardoor voor deze bedrijven een duurzame vermindering van de vraag doen ontstaan.

Als afweer tegen dit risico meent Prof. Wessels de neiging waar te nemen om de produktiemiddelen minder op de vervaardiging van speciale produkten te richten en meer op ..Funktionen", waardoor de omschakeling op gewijzigde marktomstandigheden makkelijker, althans minder moeilijk, wordt.

Hoezeer de uiteenzettingen van Prof. Wessels, waarvan het bovenstaande een fragment is, het aanhoren waard waren en hoezeer het prima vista juist lijkt, dat de moderne economie weinig of geen belangstelling meer schijnt te tonen voor de rol van de constante kosten in het ondernemingsgedrag, toch zijn wel enige kanttekeningen bij zijn betoog op hun plaats. Allereerst: het theoretisch-economisch inzicht moge in het bijzonder sinds Keynes aanmerkelijk verdiept zijn en verschillende argumenten van diens volgelingen mogen overtuigend schijnen - bijv. het effect van de ingebouw de stabilisatoren ${ }^{11}$ ) - toch zijn de nieuwere opvattingen in feite nog nauwelijks in de praktijk beproefd. Gaat men er van uit dat een doelmatige conjunctuurpolitiek in de hausse moet beginnen - tegengaan van excessieve ontwikkelingen en vorming van een krachtige deviezenreserve - , dan zou men zelfs, gezien de recente ervaringen in ons land, kunnen zeggen dat de eerste proef niet bepaald een succes geweest is.12) Bewust zullen leiders van bedrijven zich dan ook weinig aan de nieuwere inzichten gelegen laten liggen.

Ook in hun denken is de herinnering aan de dertiger jaren bewust of onbewust nog zeer levendig. En dat niet alleen in Europa, maar ook in de Verenigde Staten. ..Socially, let us assume that by 1966 the American people have finally outgrown the shock and fears of depression psychology", merkte de president van de General Electric Company in een rede op.13)

$\mathrm{Al}$ is het, indien lange perioden van ,generale Unterbeschäftigung" achterwege blijken te blijven, natuurlijk mogelijk, dat te zijner tijd een geringere drang naar kartels e.d. uit hoofde van de constante kosten problematiek wordt geregistreerd (gesteld die registratie is mogelijk), het waarschijnlijkst lijkt het toch, dat de „fixe Kosten" nog zeer geruime tijd hun invloed, of althans mede hun invloed, zullen doen gelden op het streven naar prijsafspraken e.d. of - ruimer - naar economische machtsposities door de bedrijven. Deze opvatting vindt men ook weerspiegeld in een der conclusies van het in april 1957 te Parijs onder auspiciën van de O.E.E.C. gehouden congres over automatisering: .,The changes in cost structure that follow the introduction of automation will mean that variable labour costs are replaced by fixed capital costs. This development will have a series of consequences for the position of individual firms and for the functioning of markets and these ought to be closely studied. The break-even point of firms will rise, industries will become more sensitive to changes in demand and there may develop tendencies to stabilize markets through restrictive business practices or agreements, or through public control on a national or international level".

$\mathrm{Bij}$ nadere overweging is het voorts een vraag of de $\mathrm{zgn}$. moderne economie geen belangstelling meer heeft voor het constante kostenvraagstuk. Begrijpt men onder het begrip moderne economie ook de theorie van de monopolistische concurrentie en van de marktvormen, zoals die in het eind van de dertiger jaren tot ontwikkeling is gekomen, dan is de opvatting van Prof. Wessels zeker niet geheel juist. In deze theorie spelen toch de constante kosten explicite of implicite wel degelijk een rol.

m a b blz. 56 
Zo merkt bijv. Prof. Tinbergen in zijn studie „Beperkte concurrentie” op, dat in een bepaalde situatie bij vrije concurrentie de ondernemers verliezen lijden ,als gevolg van de vaste kosten en constante grenskosten; het is, volgens verschillende auteurs, de diepere grond en een zekere rechtvaardiging van de monopolievorming".14)

Let men alleen op de naoorlogse theoretische economie, waarin de Keynesiaanse theorieën en in toenemende mate het vraagstuk van de „economics of growth" de aandacht hebben, dan lijkt Prof. Wessels wel gelijk te hebben. Het zal echter nog moeten blijken of dit niet een voorbijgaand verschijnsel is en of prijzen en kosten - en daarmede ook de problematiek van de constante kosten - te zijner tijd niet weer een meer op de voorgrond tredende positie gaan innemen.15)

In de discussies, die op de inleidingen volgden, gaf collega H. L. van den Bosch refererend aan Prof. Limperg en Prof. A. Mey een uiteenzetting van de bezwaren tegen Schmalenbach's hantering van de constante kosten, in het bijzonder het onvoldoend onderscheiden tussen kosten en verliezen. Naar aanleiding hiervan merkte de kundige discussieleider Prof. Dr K. Hax op, dat, aangenomen dat de betreffende kritiek juist is, toch die verliezen of Leerlaufkosten voor de leiding van een bedrijf als probleem blijven bestaan. Een opmerking waaraan m.i. wel enige aandacht mag worden geschonken, omdat de Nederlandse bedrijfseconomie, hoe principieel juist haar grondslagen in menig opzicht ook mogen zijn, bij haar presentatie op buitenstaanders licht de indruk kan maken, dat zij haar taak met het aangeven van juiste calculatiegrondslagen (annex de analyse van het vraagstuk van waarde en winst) beëindigd ziet.16)

De opmerkingen van Prof. Wessels over de gewoonten- en smaakwijzigingen en in verband daarmede het nut van despecialisatie van de technische produktiemiddelen zetten eveneens tot denken over de relatie bedrijfseconomie-sociale economie. Is het inderdaad zo, dat smaak en gewoonten aanmerkelijk sneller en in omvangrijker mate veranderen dan voorheen en de gevolgen daarvan voor de bedrijfshuishoudingen ingrijpender zijn dan vroeger? Is hierbij sprake van een hausseverschijnsel of zijn er dieperliggende ontwikkelingen? Voltrekt $z$ ich momenteel inderdaad in de techniek een accentverschuiving in de richting van differentiatie en dan alleen of in hoofdzaak onder invloed van veranderingen in de preferenties van de gebruikers? Heeft de bedrijfshuishouding nog andere afweermogelijkheden tegen deze wijzigingen en haar gevolgen?

Velen menen, dat de eerste vraag inderdaad bevestigend moet worden beantwoord en dat niet alleen verband moet worden gelegd met de langdurige hausse, maar evenzeer met verderreikende mentaliteitswijzigingen (From the bank account to the expens account!) De sociale economie heeft de laatste tijd verhoogde aandacht voor dit vraagstuk, o.a. in verband met het feit dat de door Keynes c.s. aangenomen stabiliteit der consumptiefunctie - één der „essentiële relaties in zijn model" - door de naoorlogse ervaringen niet meer bevestigd is.17) De verbijzonderde belangstelling, die mede daardoor voor het theoretisch en empirisch onderzoek van het consumentengedrag is ontstaan, kan ook voor de bedrijfshuishoudkunde van betekenis blijken.

Behalve het belang, dat de sociale economie bij deze verbijzondering heeft en dat meer gericht is op het algemene in het bijzondere, kunnen voor de bedrijfseconomie bovendien de meer specifieke aspecten - naar tijd, plaats. enz. - van de resultaten van bedoeld onderzoek van waarde zijn. Voor een belangwekkend overzicht van dit vraagstuk moge verwezen worden naar 
een studie van Prof. Dr L. M. Koyck: „Consumentengedrag, theorie en empirisch onderzoek".18)

De gesignaleerde tendenz tot despecialisatie van de technische produktiemiddelen herinnert aan Limperg's befaamd leerstuk van de differentiatie en specialisatie en diens principiële en genuanceerde behandeling daarvan. Naar mijn eigen ervaring is er inderdaad de laatste jaren een verhoogde belangstelling voor de betreffende problematiek in de praktijk waar te nemen. Herhaaldelijk heb ik bij allerlei besprekingen met en bezoeken aan bedrijven in verband met automatiseringsvraagstukken, zowel in de Verenigde Staten als in Europese landen, horen spreken enerzijds over de mogelijkheden, die de nieuwe ontwikkelingen bieden om in sommige gevallen flexibeler produktiemiddelen te construeren, anderzijds over de zorgen met betrekking tot de enorme bedragen die met de invoering van geautomatiseerde apparatuur waren gemoeid. Dit laatste echter niet alleen in verband met preferentiewijzigingen bij de afnemers, maar ook wegens de opmerkelijke acceleratie in de technische ontwikkeling zelve, waardoor de risico's van versnelde economische slijtage belangrijk zijn toegenomen. De bekende Amerikaanse deskundige op het gebied van de automatisering. J. Diebold, heeft op het eerste verschijnsel - flexibeler produktiemiddelen gewezen in verband met mogelijkheden voor het middelgrote en kleinere bedrijf om zich ook de voordelen van de nieuwere technieken te verwerven. ${ }^{19}$ )

Wat het laatste verschijnsel betreft, de grote bedragen die in speciale automatiseringsapparatuur worden geinvesteerd en de snelle economische veroudering, vermeldt $P$. Niland in een recente beschouwing in „Harvard Business Review ${ }^{20}$ ) de volgende uitlating van de vice president of manufacturing van de Ford Motor Company: ,Each year, with our expanding volume and changing models, we are faced with greater obsolescence of machine tools that we bought either last year or the year before. In our particular case, we obsoleted $\$ 20.000 .000$ in machine tools that we bought two years ago, because of product changes."

Hij voegt er aan toe, dat Ford in 1955 voor $\$ 116.000 .000$ aan machines e.d. kocht en vermeldt voorts nog verschillende gelijksoortige ervaringen bij andere bedrijven.

Hoe rationeel het vermoeden, dat in de huidige ontwikkelingsfase de produktiemiddelen zich meer in de richting van differentiatie bewegen, ook is, toch is het m.i. bezwaarlijk daarover iets definitiefs te zeggen, omdat het uiterst moeilijk is het gehele desbetreffende gebied te overzien. Op het terrein van de elektronische administratiemachines bijv. is juist op het ogenblik, $z$ ij het nog op zeer bescheiden schaal, de tegengestelde tendenz waar te nemen, $n l$. de vervaardiging van special purpose machines, o.a. voor spaarbanken, naast de general purpose apparatuur van Remington Rand, I.B.M. e.a. In elk geval is de strijd tussen de beide richtingen der verbijzondering, hoewel uiteraard altijd aanwezig, thans ongetwijfeld levendig.

$\mathrm{Nu}$ de vraag of een bedrijf nog andere mogelijkheden dan herorientering van zijn produktiemiddelen in de richting van differentiatie heeft om zich zo goed mogelijk te wapenen tegen de risico's van relatief snelle veranderingen in de voorkeursoordelen van zijn afnemers en in de produktietech niek. Men zou zich allereerst kunnen voorstellen dat er naar gestreefd wordt om de technische levensduur meer aan de mogelijke economische levensduur aan te passen, bijv. door mindere perfectie, mindere kwaliteit, enz. Ik heb daaromtrent vele technici gevraagd en hoewel sommigen menen dat die mogelijkheden er wel zijn, staan toch de meesten er afwijzend 
tegenover. Technici houden veelal van perfecte kwa',teit en constructie, mede omdat de kwaliteit van het eindprodukt daa van soms afhankelijk is. 21 )

Een andere mogelijkheid is uiteraard geleger in een zo zorgvuldig mogelijke verkenning van de vele factoren, dio de toekomstige rentabiliteit van de investeringen kunnen beinvloeden, waarbij o.a. niet alleen aan markt. analyse en de daarmede verband houdende bestudering van het consumentengedrag (zie boven) moet worden gedacht, maar evenzeer aan een zich rekenschap geven van de ontwikkelingsmogelijkheden in de technische produktiemiddelen en produktieprocessen, waarvan een bedrijf zich denkt te bedienen. In dit verband rijst de vraag of, in het bijzonder ook met het oog op de problematiek van het economisch groeiproces, de studie van ", het selecteren van investeringsobjecten"22) niet meer speciale aandacht van de bedrijfseconomie toekomt. Annex dit selectievraagstuk zijn uiteraard een doeltreffende afschrijvingspolitiek, een krachtig financieel weerstandsvermogen e.d. (Prof. Wessels noemde die eveneens) van betekenis.

Ook een goede leiding en organisatie - niet als een statisch gegeven maar als een voortdurend in ontwikkeling zijnd proces, men denke bijv. aan de zgn. management development - zouden tot de bedoelde wapenrusting kunnen worden gerekend, omdat zij beslissend zijn voor de slagvaardigheid van een bedrijf in kritieke situaties.

Kartels e.d. kunnen in bepaalde omstandigheden evenzeer het afweervermogen van de bedrijven tegen te snelle ontwikkelingen vergroten. Vele bedrijven bevorderen o.a. door hun reclamecampagnes meer dan eens zelf het irrationele en labiele gedrag van hun afnemers; als zij het wilden zou samenwerking op dit gebied tot matiging kunnen leiden. Een dergelijk overleg zou ook een te snel volgen van de technische vooruitgang enige tijd kunnen voorkomen.

Doeltreffender voor het individuele bedrijf is wellicht nog het creëren van een eigen economische machtspositie, al moet men van vele mogelijkheden daartoe, bekend uit de theorie van de monopolistische concurrentie, $\left.{ }^{16}\right)$ te dezer zake geen wonderen verwachten. Toch heb ik enige malen van nabij kunnen waarnemen hoe oligopolisten er in slaagden de toepassing van nieuwe technische uitvindingen in hun produkt enige tijd op te houden.

Al deze maatregelen, waarbij in het midden is gelaten in hoeverre zij met het algemeen belang stroken en of zij op grond van overheidsregelingen met betrekking tot economische machtsposities e.d. toelaatbaar zijn,23) hebben dit gemeen, dat zij in hoofdzaak van preventieve aard zijn. Veel zuiver repressieve mogelijkheden lijken mij er niet te zijn.

Wel hebben verschillende bedrijven in crisistijden tijdelijk bijzondere produkten gemaakt, maar meestal in hoofdzaak met gebruikmaking van een deel van haar bedrijfsruimte en het personeel, dat zij conte que coûte wilden behouden. Het eigenlijke machinepark kwam er, naar ik meen, weinig of niet aan te pas. ${ }^{24}$ )

Dit waren enige gedachten, die opkwamen naar aanleiding van het initiatief van de Schmalenbach Gesellschaft om aan de hand van de constante kosten problematiek sociaal. en bedrijfseconomische gezichtspunten op een wat aparte wijze met elkaar te confronteren. Het deed de Nederlandse bezoekers goed Prof. Hax - denkend aan de uiteenzettingen van Polak en de Jongh over de zgn. expansiefinanciering25) en aan Prof. Limperg's theorie van de economische kostprijs - in zijn toespraak te horen zeggen, dat in Nederland reeds 30 jaar geleden op het gebied van de bedrijfseconomie iets ,"1ngewöhnliches geleistet worden ist". 
Op de tafels lag voor de bezoekers een prospectus over een te zijner tijd te verschijnen "Handbuch der Wirtschaftswissenschaften" onder redactie van de hoogleraren Hax en Wessels, deel I "Volkswirtschaft", deel II "Betriebswirtschaft". In de inleiding, die in het prospectus is afgedrukt, ziet men temidden van de vele namen van degenen, die een rol van betekenis in de ontwikkeling van de bedrijfseconomie hebben gespeeld, met genoegen ook die van wijlen Prof. N. J. Polak vermeld. Die van Prof. Limperg ontbrak. Maar misschien wordt dat verzuim in de volgende hoofdstukken hersteld.

1) Zie "Zeitschrift für Handelswissenschaftliche Forschung", 22e jaargang (1928), blz. 243, e.v.

2) Voor Schmalenbach's kostenterminologie en -opvattingen zie Prof. Dr. H. J. van der Schroeff: „De leer van de kostprijs".

3) E. Schmalenbach: "Grundlagen der Selbstkostenrechnung und Preispolitik", 5e druk, 1930, blz. 93 e.v.

De beschouwing van K. Wittgenstein, Centraldirektor der Prager Eisen-Industrie-Gesellschaft, heet "Kartelle in Österreich". Een typische passage uit deze beschouwing laat ik hieronder volgen.

"Ich kenne in den Vereinigten Staaten von Nordamerika ein Eisenwerk (Potstown Iron Company). Als ich vor tünf Jahren dasselbe besuchte, war es in voller Thätigkeit. Ein halbes Jahr später bat mich der Chemiker dieses Werkes, ihn auf einem der unter meiner Leitung stehenden Werke praktizieren zu lassen, weil das Werk in Potstown wegen Mangess an Beschäftigung auf ein halbes Jahr eingestellt sei, und man erst in einem haben Jahre wieder zu arbeiten anfangen werde. Die Beamten werden in einem solchen Falle auf halben Gehalt gestellt und die Arbeiter entlassen, möge mit ihnen geschehen, was da wolle. In der That war der Chemiker während eines halben Jahres auf einem Werke in Böhmen und kehrte dann, als er die Nachricht bekam, dasz sein Werk wieder in Betrieb gesetzt werde, wieder nach Amerika zurück.

Dies kann man in den Vereinigten Staaten durchführen - bei uns nicht. In den Vereinigten Staaten zahlt man den Arbeiter gut, wenn man ihn braucht; es macht sich aber kein Fabrikant den leisesten Skrupel darüber, den Arbeiter auf die Strasze zu setzen, wenn er seiner nicht bedarf. Das geht in den Vereinigten Staaten an, wohin jährlich ein groszes, augezeichnetes Menschenmaterial zuströmt, das schieslich noch immer gewillt ist, sich im Westen auch unter groszen Entbehrungen anzusiedeln. Wir in Österreich und unsere Kollegen in Deutschland können nicht ein Werk auf ein halbes Jahr einstellen, um es dann wieder arbeiten zu lassen. Wir können nicht unsere Beamten auf halbes Gehalt setzen. Und was sollten wir mit unseren Arbeitern thun? Selbst wenn ein Fabrikant in Österreich das Herz hätte, den ganzen Jammer anzusehen, der mit einer solchen Einstellung verbunden ist, er würde es vor der öffentlichen Meinung nicht wagen."

4) Prof. Th. Limperg Jr: „Enige beschouwingen over kostprijs en prijsvorming als bedrijfshuishoudkundig probleem", oratie 1922. Hij vermeldde overigens "prijsregelingenovereenkomsten" wel.

Bij het overlezen van deze rede viel het mij op hoe op blz. 27 reeds elementen van wat later genoemd zou worden de theorie der "monopolistische concurrentie" worden vermeld.

5) Prof. Dr P. Lieftinck: „De toekomst der wereldmarkthuishouding”, inaugurale rede, Groningen 1934.

6) Dr P. J Verdoorn: „De verstarring der productiekosten”, Haarlem 1943, blz. 145146.

7) E. Schmalenbach: „Grundlagen der Selbstkostenrechnung und Preispolitik”, 5e druk, 1930, blz. 2.

8) M.A.B. 1946, in het bijzonder blz. 238 e.v.

9) Deze stellingen waren als volgt:

I. Die betriebswirtschaftliche Vorstellung der fixen Kosten ergibt für den Volkswirtschaftler noch nicht eindeutige Konsequenzen für den Starrheitsgrad der Unternehmungen. Es bedarf vielmehr der Analyse der Fälle, in denen die fixen Kosten die Beweglichkeit der Betriebe hemmen.

Il. Das problem stellt der Volkswirtschaftspolitik in doppelter Hinsicht Aufgaben.

a) Durch das Wachsen der fixen Kosten ist der Zusammenhang zwischen dem Schicksal des Einzelbetriebes und dem Gesamtablauf der Volkswirtschaft viel enger geworden. Die Einzelmaßnahmen der Wirtschaftspolitik müssen so ge- 
staltet werden, daß der Unternehmer das Risiko, das sich aus der Starrheit der Betriebe ergibt. sieht. Sie darf nicht dazu beitragen, daß dem Unternehmer die Konsequenzen einer wachsenden Erstarrung der Produktion uninteressant werden.

b) Der Gesamtablauf der Volkswirtschaft muB so gestaltet werden, daß Beschäftigungsschwankungen, die nicht im Interesse der Weiterentwicklung erforderlich sind, vermieden werden. Deshalb ist eine Wirtschafspolitik, die auf möglichst volle Ausnutzung aller Produktivkräfte gerichtet ist, ein wichtiges Mittel, den Gefahren, die aus der Erstarrung der Wirtschaft entstehen, entgegenzuwirken. Dabei muB jedoch eine Ausdehnung der Beschäftigung um jeden Preis verhindert werden, weil sonst die Erstarrung nur mit einer ständigen Inflationsgefahr überwunden wird.

c) Auch wenn gesamtwirtschaftlich die Nachfrage der Produktion angepaßt ist, bleibt es möglich, daß bestimmte Betriebsgruppen unter der Kostenerstarrung leiden, da sich die Struktur der Nachfrage verändert hat. Nachteile, die sich aus dieser Tatsache für einzelne Betriebe ergeben, werden in einer marktwirtschaftlichen Organisation der Volkswirtschaft niemals ganz zu vermeiden sein. Sie gehören z. T. zu den unvermeidlichen Kosten, die wir in einer Marktwirtschaft auf Grund der Konsumfreiheit aufzubringen haben. Allerdings kann der einzelne Unternehmer durch Ausnutzung der Informationen, die die Volkswirtschaftslehre auf Grund relativ zuverlässiger Methoden für die Bedarfsentwicklung gibt, den Anpassungsgrad seines Betriebes heben.

10) Op ongeveer dezelfde wijze geformuleerd door Prof. Dr. P P. van Berkum in zijn interessante uiteenzetting .Van Keynes tot onze tijd" (Leiden 1957).

..Methodologisch betekende de verschijning van de General theorie een accentverschuiving van de sfeer van productie en prijzen naar de sfeer van inkomen en verbruik. Niet prijzen, maar inkomens en bestedingen nemen de centrale plaats in het economisch gebeuren in. Het initiatief tot het benutten van het productie-apparaat wordt van de aanbieders naar de verschillende categorieën vragers verlegd."

11) Zie o.a. Prof. Dr H. J. Witteveen: „Is de wereldeconomie minder conjuncturugevoelig geworden?", stellingen Accountantsdag N.I.v.A. 1954.

12) Bedacht dient evenwel te worden, dat deze ervaring nog niet tegen de juistheld van de theorie behoeft te pleiten. Wellicht is veeleer het vraagstuk, dat de nieuwere inzichten nog te weinig in het maatschappelijke en politieke denken en doen zijn opgenomen en dat nagegaan en afgewacht moet worden in hoeverre deze integratie mogelijk is.

13) Ralph J. Cordiner: „New Frontiers for Professional Managers”, New York 1956, blz. 92.

14) Prof. Dr T. Tinbergen: „Beperkte concurrentie”, Leiden 1946, blz. 88.

Later (blz. 121) geeft hij als zljn mening te kennen, dat ,een toenemende monopolisatie niet kan worden gemotiveerd door een toenemen der vaste kosten. Door Verdoorn is nl. aannemelijk gemaakt, dat een zodanige toeneming op zijn minst dubieus is." Het lijkt mij toe, dat hij hierbij voorbij ziet, dat Verdoorn daarnevens aan het slot van zijn studie de reeds gesignaleerde opmerking heeft gemaakt, dat het in deze materie misschien niet zozeer op de relatieve toeneming der constante kosten als op hun absolute hoogte aankomt. Overigens pleit Tinbergen voor een deugdelijk en breed opgezet onderzoek naar het werkeliikheidsgehalte van de theorie der beperkte concurrentie, omdat er op dat hele gebled "nog zoveel in het duister" ligt.

15) a. Zie ook Prof. Dr P. P. van Berkum: „Van Keynes tot onze tijd”, blz. 8: „Dit betekende ntet, dat de vraagstukken van productie en prijsvorming, de problemen van kostprijs en winst en de door een werkzame concurrentie in de juiste banen te brengen allocatie der productiefactoren door Keynes overbodig werden geacht, doch hif zag dit zo, dat, indien men in staat zou zijn om de altijd dreigende insufficiëntie van de vraag op te vangen en daardoor een volledig bezette economie te krijgen, de klassieke theorema's van het productie- en prijsvormingsmechanisme eerst ten volle tot hun recht zouden komen." b. In de praktijk van de economische politiek in ons land spelen kosten en prijzen - men denke aan het loon-en prijsbeleid - overigens wel een rol van betekents.

16) Prof. Limperg merkt op blz. 27 van zijn eerder vermelde rede van 1922 op. na enige middelen te hebben opgesomd waarvan de bedrijfshuishouding zich bedient ,in haar voortdurende worsteling met de algemeene matschapplj om zich zoo lang mogellik van de nivellerende werking van de algemeene prijsvorming te onttrekken", .,deze middelen noodigen op zichzelf den bedrilfshuishoudkundige tot nader onderzoek uit". Vergis ik mil als ik meen, dat van dit onderzoek in ons land weinig is gekomen?

Vergelijk ook de opmerking van Dr J. L. Mey - hoewel niet speciaal op de Nederlandse bedrijfseconomie betrekking hebbend - in zijn artikel "Kostprijs en prijsleer in soclale economie en bedrijfseconomie", M.A.B. 1947, blz. 319 e.v.: "Hoewel het geenszins haar 
bedoeling is, dat de bedrijfshuishouding zich t.o.v. deze verliezen slechts lijdelijk zou hebben te gedragen, heeft naast de analyse van de kostprijs de studie omtrent de gedragingen van de bedrijfshuishouding t.a.v. laatstgenoemde factoren aanvankelijk toch een bescheiden plaats ingenomen."

17) Zie Prof. van Berkum: "Van Keynes tot onze tijd", blz. 17; ook de hieronder volgende noot.

18) „Verbruik en sparen in theorie en praktijk", Haarlem (z.j.).

19) Zie "Hearings before the Subcommittee on Economic Stabilization of the Joint Committee on the Economic Report", Washington 1955, blz. 9 en blz. 20 (New approach to machine design).

20) "Investing in special automatic equipment", Harvard Business Review, novemberdecember 1957.

21) Wel herinner ik mij uitlatingen van verschillende technici, die voor bedrijfsstudie fabrieken in de V.S. bezocht hadden, dat de afwerking van gereedschappen en machines enz. zoveel minder degelljk was dan bij ons. Ik weet echter niet of dit bewust gedaan is met het oog op verkorting van de technische levensduur. 1957.

22) Zie Prof. Dr H. J. Kruisinga: „Het selecteren van investeringsprojecten”, Leiden

23) In dit verband zij opgemerkt, dat Schmalenbach's mening, dat in de toekomst de bedrijven ,ihr Monopol vom Staate" zouden ontvangen, vergaand bewaarheid lijkt te worden. In het Euromarktverdrag is in beginsel een kartelverbod opgenomen. Zie art. 85 van het verdrag inzake de Europese Economische Gemeenschap en het artikel van $\mathrm{Mr}$ G. E. Kruseman, „De Nederlandse kartelbepalingen en die van de E.E.G.", in E.-S.B. van 4 december 1957.

24) Een $Z$ weedse hoogleraar was daaromtrent op onderzoek uitgegaan en vermeldde in het debat verschillende praktijkvoorbeelden; de Ericsson Telefoonmaatschappij bijv. had tijdelijk keukengerei gemaakt.

25) Polak zelf vermeldt ook Busé en v. d. Heyden.

\section{ZUSAMMENFASSUNG}

\section{SOZIALWIRTSCHAFT UND BETRIEBSWIRTSCHAFT}

Im November 1957 hat die Schmalenbach Gesellschaft in Köln eine Arbeitstagung zur Feier ihres 25-jährigen Bestehens abgehalten. Als Thema der Beratung hatte man dazu „Bessere Marktanpassung durch unternehmerisches Planen" gewählt, mit als Nebentitel "Wie begegnet die Unternehmersleitung der wachsenden Ausweitung der fixen Kosten und ihrer Auswirkung auf das Unternehmerrisiko?" Dieses Thema stand im Zusammenhang mit einem 1928 in Wien von Schmalenbach gehaltenen Vortrag „Die Betriebswirtschaftslehre an der Schwelle der neuen Wirtschaftsverfassung", in welchem Schmalenbach engen Zusammenhang feststellte zwischen der relativen Zunahme der fixen Kosten - die er als Tatsache voraussetzt - und der Bildung von Kartellen als Abwehr gegen die Gefahren ständiger Kosten in Perioden längerer Unterbeschäftigung.

Die Schmalenbach Gesellschaft hat nunmehr einen Sozialwirtschaftler, Prof. Dr. Th. Wessels, und einen Betriebswirtschaftler, Prof. Dr. Th. Beste, eingeladen, vom Standpunkt der Gegenwart aus ihre Anschauung hinsichtlich der Problematik der fixen Kosten klarzulegen. Ersterer tat dies unter dem Titel „Wachsende Starrheit der Unternehmungen und ihre Ursachen", letzterer sprach über „GröBere Elastizität durch unternehmerisches Planen vom Standpunkt der Wissenschaft".

Der Verfasser bespricht nunmehr einige Gesichtspunkte von Prof. Wessels' interessantem Vortrag. Insbesondere geht er dabei auf zwei Punkte in dessen Rede näher ein. Zunächst, daB die modernen Nationalökonomen sich in erster Linie mit der Problematik des Nationaleinkommens beschäftigen, mit den Aufwänden, den Einkommenströmen und namentlich der 
Möglichkeit, diese auf einem angemessenen Niveau zu halten, wodurch ein längerer und tiefgehender Niedergang des Wirtschaftslebens verhütet werden kann und wodurch Schmalenbachs Problematik der fixen Kosten als allgemeine Erscheinung nicht mehr auf die Tagensordnung erscheinen wird.

Obwohl er die Richtigkeit von Prof. Wessels' Gedankengang gewissermaßen anerkennt, gestattet der Verfasser sich einige Bemerkungen. $\mathrm{Zu}$ nächst, da $B$ die neueren wirtschaftlichen Auffassungen noch in der Praxis erprobt werden müßten und daß man die Ergebnisse bis jetzt noch nicht optimistisch beurteilen könne, sodaß Unternehmer in der Praxis, auch indem sie sich die Krisis der dreißiger Jahre erinnern, in ihren Erwägungen und ihrem Verhalten die fixen Kosten schwer wiegen lassen würden und letztere deswegen beim Streben nach Bildung wirtschaftlicher Machstellungen auch nach wie vor eine wichtige Rolle spielen würden.

Weiter bemerkt der Verfasser, daB, wenn man zur neuzeitlichen Oekonomik auch die Theorie der monopolistischen Konkurrenz rechne, man allerdings von Interesse für die Kostenproblematik sprechen könne, weil in dieser Theorie die fixen Kosten explizite oder implizite ganz bestimmt eine Rolle spielen.

Der Verfasser bezieht sich weiter auf eine AeuBerung des Herrn Prof. Dr. P. P. van Berkum, der darauf hinweist, daß Keynes gerade der Ansicht sei, bei vollständig besetzter Oekonomie würden die klassischen Theorien des Produktions - und Preisbildungs-Mechanismus erst recht zur Geltung gelangen.

Darauf geht der Verfasser summarisch auf einen zweiten Punkt der Ausführungen von Prof. Wessels ein, nämlich, daß auch bei allgemeiner Nachfrage auf hohem Niveau trotzdem bestimmte Unternehmungen mit großen fixen Kosten durch plötzliche und rasche Aenderungen von Geschmack und Gepflogenheiten des Publikums mit unerwarteten Problemen zu kämpfen haben mögen. Prof. Wessels glaubt deswegen eine Tendenz nach erhöhter Differenzierung (Vgl. Limpergs Lehrstück über Spezialisierung gegen Differenzierung) zu bemerken. Der Verfasser vergleicht diese Wahrnehmung mit eignen Erfahrungen und einer rezenten Beobachtung in den Vereinigten Staaten. Weiter bespricht er die Bedeutung der neuen wirtschaftlichen Spezialisierung - der theoretischen und empirischen Untersuchung des Verbraucherverhaltens - in diesem Zusammenhang und für die Betriebswirtschaft überhaupt.

Schließlich weist der Verfasser noch auf den interessanten Versuch hin, der, wie aus einem in der Versammlung anwesenden Prospekt hervorgeht. angestellt wird, ein gemeinschaftliches Werk über die Sozial- und Betriebswirtschaft zu veröffentlichen. Er erwähnt dazu, daß in der im Prospekt enthaltenen Einleitung auch der niederländische Gelehrte Prof. N. J. Polak genannt werde, daB jedoch der Name Prof. Th. Limpergs, der ja mehr als wer auch eingehend sein Gepräge auf die Emanzipation und Entwicklung der Betriebswirtschaft als Wissenschaft gedrückt habe, fehle. Er äuBert die Hoffnung, daB dieses Versäumnis in den weiteren Abschnitten gutgemacht werden möge. 